Joanna M. Karolczak

\title{
Możliwość podjęcia interwencji poselskiej u komornika sądowego ${ }^{1}$
}

Possibility of taking Deputies' intervention in a court bailiff: The Act on the Exercise of the Mandate of Deputy or Senator does not provide for the right of a Deputy to intervene with a court bailiff. The intervention concerning bailiff's actions may be directed by a Deputy to the Minister of Justice, as an authority exercising supervision over the activity of bailiffs and their self-government.

\author{
Keywords: intervention | bailiff | Deputy \\ Słowa kluczowe: interwencja | komornik | poseł
}

Radca prawny, ekspert ds. legislacji BAS; joanna.karolczak@sejm.gov.pl.

\section{Przedmiot opinii}

Opinia zawiera odpowiedź na pytanie: czy poseł na Sejm RP, działając na podstawie ustawy o wykonywaniu mandatu posła i senatora, może podjąć interwencję poselską u komornika sądowego. Autorzy pytania doprecyzowali, że chodzi o interwencję poselską w przypadku zgłaszanych przez obywateli czynności komorniczych, które budzą wątpliwości, czy zostały podjęte zgodnie z obowiązującym prawem.

Opinia została przygotowana $\mathrm{z}$ uwzględnieniem następujących aktów prawnych, według stanu prawnego na dzień sporządzenia opinii:

- Konstytucji Rzeczypospolitej Polskiej z 2 kwietnia 1997 r., Dz.U. nr 78, poz. 483 , ze zm.,

- ustawy z 9 maja 1996 r. o wykonywaniu mandatu posła i senatora, Dz.U. 2016, poz. 1510, ze zm.; dalej: ustawa o wykonywaniu mandatu,

- ustawy z 29 sierpnia 1997 r. o komornikach sądowych i egzekucji, Dz.U. 2017, poz. 1277 , ze zm.; dalej: ustawa o komornikach,

1 Opinia prawna $w$ sprawie interpretacji art. 20 ustawy z 9 maja 1996 r. o wykonywaniu mandatu posła i senatora w kontekście możliwości podjęcia interwencji poselskiej u komornika sądowego sporządzona 16 stycznia 2018 r. na zlecenie Klubu Poselskiego Kukiz'15; BAS-WAP 18/18. 
- ustawy z 17 listopada 1964 r. - Kodeks postępowania cywilnego, Dz.U. 2016, poz. 1822, ze zm.; dalej: k.p.c.

\section{Interwencja poselska}

1. Prawo do interwencji poselskiej zostało uregulowane w art. 20 ustawy o wykonywaniu mandatu, który w ust. 1 stanowi: Poseł lub senator ma prawo podjać - w wykonywaniu swoich obowiązków poselskich lub senatorskich - interwencje $w$ organie administracji rządowej $i$ samorzadu terytorialnego, zakładzie lub przedsiębiorstwie państwowym oraz organizacji społecznej, a także w jednostkach gospodarki niepaństwowej dla załatwienia sprawy, która wnosi we własnym imieniu albo $w$ imieniu wyborcy lub wyborców, jak również zaznajamiać się z tokiem jej rozpatrywania.

Definiując pojęcie „interwencji”, autor Komentarza do ustawy o wykonywaniu mandatu ${ }^{2}$ odwołuje się do leksykalnego jej pojęcia rozumianego jako wtrącanie się w jakąś sprawę: wywieranie lub wywarcie [...] wpływu (przez jakieś podmioty) na bieg tych spraw, np. po to by komuś pomóc lub by zapobiec konfliktom i podkreśla, że nie ma żadnych przesłanek, by nadawać pojęciu „interwencja” odmiennego znaczenia niż to, jakie wynika z przytoczonego znaczenia słownikowego, a zatem: przyjać trzeba, że taka interwencja jest po prostu działaniem posła lub senatora, który ma zamiar uzyskania informacji o przebiegu sprawy rozpatrywanej przez dany podmiot, badź też doprowadzenia do jej ostatecznego rozstrzygnięcia. Podobnie M. Poślednik zauważa, że interwencja stanowi szczególny i wyjątkowy środek prawny przyznany posłom, której celem nie jest jednak wszczęcie określonego postępowania, załatwienie ani wpłynięcie na merytoryczny zakres sprawy, lecz ingerencja w tok toczącego się już postępowania ${ }^{3}$.

Zakres podmiotów, do których można wystąpić z interwencją, jest wskazany w omawianym przepisie. Może to być organ administracji rządowej i samorządu terytorialnego, zakład lub przedsiębiorstwo państwowe, organizacja społeczna, a także jednostka gospodarki niepaństwowej. Pomijając w tym miejscu rozważania na temat nieadekwatności pojęć użytych w tym przepisie ${ }^{4}$, można zauważyć, że nie wymieniono w tym przepisie komorników.

2 P. Uziębło [w:] Komentarz do ustawy o wykonywaniu mandatu posła i senatora, red. K. Grajewski, Warszawa 2014, s. 281 i n.

3 M. Poślednik, Interwencja poselska $z$ art. 20 ust. 1 ustawy o wykonywaniu mandatu posła i senatora, „Przegląd Sejmowy” 2010, nr 3, s. 201-202.

4 O czym w wielu opiniach BAS, w tym w szczególności w: P. Chybalski, I. Galińska-Rączy, E. Gierach, J.M. Karolczak, W. Odrowąż-Sypniewski, Opinia prawna w sprawie kierunków zmian ustawy z 9 maja 1996 r. o wykonywaniu mandatu posła i senato$r a$, BAS-WAUiP-WAL 116/15, BAS-WAUiP-WAL 1761/16. 
2. Z treści art. 1 ustawy o komornikach wynika, że komornik sądowy jest funkcjonariuszem publicznym działającym przy sądzie rejonowym. Komornik to organ egzekucji sądowej powiązany z władzą sądowniczą, lecz nie będący jej organem $^{5}$. Jest organem państwa powołanym do wykonywania orzeczeń sądowych w drodze przymusowej egzekucji świadczeń pieniężnych i niepieniężnych, a także wykonywania innych czynności określonych w ustawach ${ }^{6}$. Komornik działa przy sądzie rejonowym, nie jest jednak pracownikiem sądu ${ }^{7}$ Komornik jest powiązany organizacyjnie i funkcjonalnie $\mathrm{z}$ władzą sądowniczą, będącą wyodrębnioną konstytucyjnie postacią władzy publicznej. Nie jest jednak organem władzy sądowniczej, a przede wszystkim nie sprawuje wymiaru sprawiedliwości, powierzonego w art. 175 ust. 1 Konstytucji RP sądom ${ }^{8}$.

W myśl art. 3 ust. 1 ustawy o komornikach przy wykonywaniu czynności komornik podlega orzeczeniom sądu i prezesowi sądu rejonowego, przy którym działa. Natomiast zgodnie z art. 64 ust. 1 i 2 nadzór zwierzchni nad działalnością komorników i działalnością samorządu komorniczego sprawuje Minister Sprawiedliwości. Nadzór ten nie może wkraczać w działania podlegające nadzorowi sądu. Nadzór nad działalnością komorników sprawuje Minister Sprawiedliwości przez prezesów sądów okręgowych, sędziów wizytatorów, a w zakresie kontroli finansowej - przez osoby upoważnione.

3. Z powyższych przepisów należy wyprowadzić wniosek, że ewentualną interwencję poselską dotyczącą komornika należy skierować do podmiotu, który sprawuje zwierzchni nadzór nad komornikiem w zakresie niepodlegającym nadzorowi sądu, czyli do Ministra Sprawiedliwości. Jest on także organem, do którego - zgodnie z treścią art. 20 ust. 1 ustawy o wykonywaniu mandatu - interwencja poselska może być skierowana (organ administracji rządowej). Natomiast komornik sądowy nie jest podmiotem, do którego poseł może skierować interwencję w trybie przywołanego art. 20.

4. Należy zwrócić uwagę, że zgodnie z art. 3 ust. 2 ustawy o komornikach, prezes sądu rejonowego, przy którym działa komornik, sprawuje nadzór nad jego działalnością, a w szczególności:

1) ocenia szybkość, sprawność i rzetelność postępowania poprzez badanie, czy w konkretnych sprawach nie zachodzi nieuzasadniona przewlekłość w podejmowaniu czynności,

2) kontroluje prawidłowość prowadzenia biurowości i rachunkowości kancelarii komorniczej,

5 A. Machnikowska, Komentarz do art. 1 [w:] Ustawa o komornikach sadowych i egzekucji. Komentarz, red. J. Świeczkowski, 2012, LEX.

6 A. Barańska, Status prawny komornika sq̨dowego i mienia kancelarii komorniczej, „Przegląd Prawa Egzekucyjnego” 2008, nr 1-2.

7 M. Bieżuński, P. Bieżuński, Ustawa o komornikach sądowych i egzekucji. Komentarz, 2010, LEX, komentarz do art. 1.

8 W. Tomalak, Status ustrojowy i procesowy komornika sądowego, 2014, LEX. 
3) bada kulturę pracy, w tym przestrzeganie wyznaczonych terminów czynności i przyjmowania interesantów oraz utrzymywanie kancelarii komorniczej na poziomie odpowiednim do godności urzędu i posiadanych środków,

4) zawiadamia sąd o potrzebie wydania komornikowi zarządzeń $w$ trybie art. $759 \$ 2$ Kodeksu postępowania cywilnego.

Natomiast w myśl art. 3 ust. 4 ustawy o komornikach prezes sądu rejonowego, przy którym działa komornik, jest uprawniony tylko do rozpoznawania skarg i zażaleń niestanowiących przedmiotu rozpoznania sądu w trybie skargi na czynności komornika z art. 767 k.p.c. ${ }^{9}$. Nadzór prezesa sądu rejonowego nad działalnością komornika nie może więc wkraczać w działania komornika podlegające nadzorowi sądu, czyli w czynności egzekucyjne, innymi słowy, nie może polegać na weryfikacji zasadności tych czynności ani ich zgodności z prawem. Zakres nadzoru administracyjnego prezesa sądu rejonowego ograniczony został do oceny szybkości, sprawności i rzetelności postępowania, kontroli prawidło-

$9 \quad$ Art. 767. \$1. Na czynności komornika przysługuje skarga do sądu rejonowego, jeżeli ustawa nie stanowi inaczej. Dotyczy to także zaniechania przez komornika dokonania czynności. Do rozpoznania skargi na czynności komornika właściwy jest sąd, przy którym działa komornik. Jeżeli do prowadzenia egzekucji został wybrany komornik poza właściwościa ogólną, skarge rozpoznaje sąd, który byłby właściwy według ogólnych zasad.

$\$ 11$. Skarga nie przysługuje na zarzadzenie komornika o wezwaniu do usunięcia braków pisma, na zawiadomienie o terminie czynności oraz na uiszczenie przez komornika podatku od towarów i ustug.

$\$ 2$. Skargę może złożyć strona lub inna osoba, której prawa zostały przez czynności lub zaniechanie komornika naruszone bądź zagrożone.

$\$ 3$. Skarga na czynność komornika powinna czynić zadość wymaganiom pisma procesowego oraz określać zaskarżona czynność lub czynność, której zaniechano, jak również wniosek o zmianę, uchylenie lub dokonanie czynności wraz z uzasadnieniem.

$\$ 4$. Skarge wnosi się $w$ terminie tygodniowym od dnia dokonania czynności, gdy strona lub osoba, której prawo zostało przez czynność komornika naruszone bądź zagrożone, była przy czynności obecna lub była o jej terminie zawiadomiona; $w$ innych przypadkach - od dnia zawiadomienia o dokonaniu czynności strony lub osoby, której prawo zostało przez czynność komornika naruszone bądź zagrożone, a w braku zawiadomienia - od dnia powzięcia wiadomości przez skarżącego o dokonanej czynności. Skarge na zaniechanie przez komornika dokonania czynności wnosi się $w$ terminie tygodniowym od dnia, w którym skarżacy dowiedział się, że czynność miała być dokonana.

$\$ 5$. Skarge wnosi się do komornika, który dokonał zaskarżonej czynności lub zaniechał jej dokonania. Komornik $w$ terminie trzech dni od dnia otrzymania skargi sporzadza uzasadnienie zaskarżonej czynności, o ile nie zostało ono sporzadzone wcześniej, albo przyczyn jej zaniechania i przekazuje je wraz ze skarga i aktami sprawy do właściwego sąu, chyba że skarge w całości uwzględnia. O uwzględnieniu skargi komornik zawiadamia skarżącego oraz zainteresowanych, których uwzględnienie skargi dotyczy. 
wości prowadzenia biurowości i rachunkowości kancelarii komorniczej i kultury pracy komornika ${ }^{10}$.

Podstawowym środkiem zaskarżenia w postępowaniu egzekucyjnym jest skarga na czynności komornika, która zarazem stanowi środek nadzoru sądu nad komornikiem z art. 767 k.p.c. Służy ona, co do zasady, na wszelkie czynności komornika - rozstrzygające i faktyczne - oraz na zaniechanie dokonania przez niego czynności. Natomiast Minister Sprawiedliwości sprawuje nadzór administracyjny. Według A. Marciniaka ${ }^{11}$ nadzór zwierzchni Ministra Sprawiedliwości nad działalnością komorników sądowych i organów samorządu komorniczego nie jest jednolity i należy wyróżnić dwa rodzaje tegoż nadzoru - nadzór ogólny, którego przejawem są regulacje zawarte w art. 66 ust. 1 i $3^{12}$, art. 67 ust. 2 i $3^{13}$, art. 68 ust. $1^{14}$, art. $69^{15}$ ustawy o komornikach oraz nadzór szczególny na pod-

10 M. Dziewulska, Komentarz do art. 3 ustawy [w:] Ustawa o komornikach sadowych i egzekucji. Komentarz, red. J. Świeczkowski, 2012, LEX.

11 Idem, Nadzór nad komornikiem według ustawy o komornikach sądowych i egzekucji [w:] Analiza i ocena ustawy o komornikach sądowych i egzekucji, red. K. Lubiński, Sopot 2000, s. 164.

12 Art. 66 ust. 1. Komornik jest obowiązany złożyć przed dniem 1 lutego każdego roku roczne sprawozdanie ze swojej działalności. (...)

3. Minister Sprawiedliwości, po zasięgnięciu opinii Krajowej Rady Komorniczej, określi, $w$ drodze rozporządzenia, zakres sprawozdania, o którym mowa $w$ ust. 1, biorąc pod uwage, że dane wskazywane w sprawozdaniu powinny stworzyć odpowiednie warunki do oceny stanu egzekucji w obszarze właściwości sądu apelacyjnego, w szczególności pod kątem sprawności i skuteczności egzekucji oraz występujących tendencji w zakresie ruchu spraw egzekucyjnych.

13 Art. 67 ust. 2. Krajowa Rada Komornicza przedkłada Ministrowi Sprawiedliwości uchwały i protokoły walnych zgromadzeń izb komorniczych oraz Krajowego Zjazdu Komorników, a także własne sprawozdanie roczne wraz z bilansem, $w$ terminie dwóch tygodni od dnia ich otrzymania lub sporzadzenia.

3. Minister Sprawiedliwości może zażadać, w razie potrzeby, od Prezesa Krajowej Rady Komorniczej i rad izb komorniczych również innych dokumentów niż określone w ust. 2. 4. Rada izby komorniczej przekazuje prezesowi właściwego sąu okręowego odpisy protokołów wizytacji, wniosków i poleceń powizytacyjnych, o których mowa w ust. 1 .

14 Art. 68 ust. 1. Minister Sprawiedliwości może zwrócić się do Sądu Najwyższego z wnioskiem o uchylenie uchwały samorzadu komorniczego sprzecznej z prawem $w$ terminie 6 miesięcy od dnia jej otrzymania.

15 Art. 69. Minister Sprawiedliwości, po zasięgnięciu opinii Krajowej Rady Komorniczej określi, $w$ drodze rozporzadzenia, szczegółowe przepisy o biurowości i ewidencji operacji finansowych kancelarii komorniczych. W rozporządzeniu należy uwzględnić potrzeby szczegółowej ewidencji spraw prowadzonych $w$ kancelarii, uwidocznienia przebiegu czynności, zapewnienia przejrzystości wpisów oraz odzwierciedlenia wszystkich operacji finansowych dokonywanych przez komornika, a także stwarzania możliwości kontroli poprawności dokonywanych operacji finansowych. 
stawie art. 64 ust. $2^{16}$ ustawy o komornikach, a podział ten należy uzasadnić m.in. różnym charakterem czynności i środków w ramach nadzoru stosowanego przez Ministra Sprawiedliwości.

Minister Sprawiedliwości w ramach nadzoru nad działalnością komorników sądowych uprawniony jest również do oceny zgodności z prawem czynności podjętych przez komornika w zakresie niezbędnym do korzystania przez Ministra Sprawiedliwości z przyznanych mu uprawnień ustawowych, takich jak możliwość: odwołania komornika z zajmowanego stanowiska z powodu rażącego lub uporczywego naruszenia przepisów prawa, zawieszenia komornika w czynnościach czy wystąpienia $\mathrm{z}$ wnioskiem o wszczęcie postępowania dyscyplinarnego wobec komornika, opartego na zarzucie rażącej obrazy przepisów prawa.

Minister Sprawiedliwości nie jest natomiast uprawniony do zmiany, uchylenia lub nakazania komornikowi podjęcia wskazanych czynności egzekucyjnych, określonych w przepisach ustawy - Kodeks postępowania cywilnego. Tego rodzaju ingerencja w działalność komorników w postępowaniu egzekucyjnym jest możliwa jedynie przez sąd $\mathrm{w}$ ramach sprawowania nadzoru judykacyjnego, z wykorzystaniem prawem przewidzianych środków, w szczególności wskutek uwzględnienia przez sąd skargi na czynności komornika, wnoszonej i rozpatrywanej w trybie przepisów art. 767 k.p.c. Taką skargę może wnieść nie tylko strona postępowania egzekucyjnego, ale również inna osoba, której prawa zostały przez czynności lub zaniechanie komornika naruszone bądź zagrożone. Nadto, zgodnie $\mathrm{z}$ art. $759 \$ 2^{17}$ k.p.c., sąd może z urzędu wydawać komornikowi zarządzenia zmierzające do zapewnienia należytego wykonania egzekucji oraz usuwać spostrzeżone uchybienia. Czynności sądu na podstawie powyższego przepisu mogą być podejmowane na wniosek, a nawet $\mathrm{z}$ urzędu po zasygnalizowaniu sądowi potrzeby rozważenia wdrożenia nadzoru przewidzianego w tym przepisie.

5. Kwestie związane z problematyką podejmowania interwencji poselskich i senatorskich u komorników były przedmiotem następujących interpelacji i oświadczeń:

- interpelacja poselska nr 23121/VI kad. w sprawie uchylania się komorników sądowych od odpowiedzi na interwencję poselską, na przykładzie komornika sądowego w S., w odpowiedzi na którą skonstatowano, że z treści art. 20 ust. 1 i 2 ustawy o wykonywaniu mandatu niewątpliwie wynika prawo posła i senatora do podjęcia interwencji, ale wyłącznie we wskazanych w powołanym przepisie podmiotach, wśród których ustawodawca nie wymienił komornika; zgodnie z literalną wykładnią powyższego przepisu komornik nie ma zatem

16 Art. 64 ust. 2. Nadzór nad działalnościa komorników sprawuje Minister Sprawiedliwości przez prezesów sądów okręgowych, sędziów-wizytatorów, a w zakresie kontroli finansowej-przez osoby upoważnione.

17 Art. 759 \$2. Sąd może z urzędu wydawać komornikowi zarządzenia zmierzające do zapewnienia należytego wykonania egzekucji oraz usuwać spostrzeżone uchybienia. 
obowiązku udzielania odpowiedzi na interwencje składane przez parlamentarzystów,

- interpelacja nr 7910/VII kad. w sprawie zablokowania przez komornika sprzedaży gruntu należącego do petenta, gdzie z kolei w odpowiedzi wskazano, że z uwagi na charakter nadzoru nad działalnością komorników sądowych Minister Sprawiedliwości nie podejmie interwencji w sprawie egzekucyjnej wskazanej przez posła; zgodnie bowiem z art. 64 ust. 1 i 2 ustawy o komornikach sądowych i egzekucji Minister Sprawiedliwości sprawuje nad działalnością komorników sądowych nadzór administracyjny, który sprowadza się do badania szybkości i sprawności postępowania egzekucyjnego oraz kultury urzędowania i etycznych aspektów działalności komornika, a w szczególności do badania, czy nie zachodzi nieuzasadniona przewlekłość w podejmowaniu czynności; nadzór ten nie może wkraczać w działania podlegające nadzorowi sądu; Minister Sprawiedliwości nie jest uprawniony do uchylenia, zmiany lub nakazania komornikowi podjęcia określonych czynności egzekucyjnych; tego rodzaju działania wobec komornika może podjąć wyłącznie niezawisły sąd w drodze nadzoru judykacyjnego uregulowanego w przepisach Kodeksu postępowania cywilnego m.in. poprzez wydawanie komornikowi z urzędu zarządzeń zmierzających do zapewnienia należytego wykonania egzekucji oraz usuwanie spostrzeżonych uchybień (art. $759 \$ 2$ k.p.c.),

- oświadczenie senatora S.G. z 10 maja 2012 r. (VII kad.) w sprawie uchylania się przez komornika sądowego od odpowiedzi na interwencję senatora podjętą w trybie art. 20 ust. 1 i 2 ustawy; w odpowiedzi udzielonej przez podsekretarza stanu w Ministerstwie Sprawiedliwości zwrócono uwagę, że w przypadku skierowania do komornika interwencji posła lub senatora powinien on niezwłocznie przekazać ją sprawującemu zwierzchni nadzór nad komornikami Ministrowi Sprawiedliwości i o tym fakcie zawiadomić parlamentarzystę,

- interpelacja nr 15230/VIII kad. w sprawie nieudzielania odpowiedzi przez komorników sądowych na interwencje posłów i senatorów, gdzie wskazano, że komornicy sądowi określani w orzecznictwie Trybunału Konstytucyjnego jako „pomocniczy organ wymiaru sprawiedliwości” nie należą do żadnej z kategorii podmiotów obowiązanych, wymienionych w art. 20 ust. 1 ustawy o wykonywaniu mandatu; trzeba jednak zauważyć, że Minister Sprawiedliwości sprawujący w granicach art. 64 ust. 1 ustawy o komornikach zwierzchni administracyjny nadzór nad działalnością komorników sądowych, należy do organów wymienionych tak w art. 16 ust. 1, jak i w art. 20 ust. 1 ustawy o wykonywaniu mandatu. Korzystając z przysługujących mu kompetencji do żądania od komorników stosownych informacji, Minister Sprawiedliwości przeprowadza postępowanie wyjaśniające we własnym zakresie i udziela odpowiedzi na kierowane do niego interwencje parlamentarzystów również w zakresie dotyczącym postępowań egzekucyjnych. 


\section{Podsumowanie}

Poseł nie może podjąć interwencji u komornika sądowego, bowiem art. 20 ustawy o wykonywaniu mandatu posła i senatora nie przewiduje takiego uprawnienia.

Interwencja w sprawie działań komornika może być skierowana przez posła do Ministra Sprawiedliwości, jako organu sprawującego nadzór zwierzchni nad działalnością komorników i działalnością samorządu komorniczego.

\section{Bibliografia}

Barańska A., Status prawny komornika sądowego i mienia kancelarii komorniczej, „Przegląd Prawa Egzekucyjnego" 2008, nr 1-2.

Bieżuński M., Bieżuński P., Ustawa o komornikach sądowych i egzekucji. Komentarz, 2010, LEX, komentarz do art. 1.

Dziewulska M., Komentarz do art. 3 ustawy [w:] Ustawa o komornikach sadowych i egzekucji. Komentarz, red. J. Świeczkowski, 2012, LEX.

Dziewulska M., Nadzór nad komornikiem według ustawy o komornikach sadowych i egzekucji [w:] Analiza i ocena ustawy o komornikach sądowych i egzekucji, red. K. Lubiński, Sopot 2000.

Machnikowska A., Komentarz do art. 1 [w:] Ustawa o komornikach sadowych i egzekucji. Komentarz, red. J. Świeczkowski, 2012, LEX.

Poślednik M., Interwencja poselska $z$ art. 20 ust. 1 ustawy o wykonywaniu mandatu posła i senatora, „Przegląd Sejmowy”, 2010, nr 3.

Tomalak W., Status ustrojowy i procesowy komornika sądowego, 2014, LEX.

Uziębło P. [w:] Komentarz do ustawy o wykonywaniu mandatu posła i senatora, red. K. Grajewski, Warszawa 2014. 